\title{
Performance Analysis of Real Estate Management Entities Based on DEA Model
}

\author{
Tao Fanghong \\ Yunnan College of Business Management, Yunnan, China, 650304
}

Keywords: College, Students', socialist core values, problems, Countermeasures.

Abstract: Based on the financial report data of Listed Companies in 2015 and taking profitability as the criterion, this paper selects 40 real estate enterprises as samples, and analyzes the operation performance of the real estate industry by using data envelopment analysis method. The results show that the scale benefit of the industry still exists, but it is no longer significant, and the development mode of the industry is in place. In the period of obvious change, the operation and management of real estate enterprises are becoming more and more mature, and the optimal allocation of resources has been basically achieved at the macro level of resource utilization, but the industry needs to be further improved in fine management, practical human resources management, supervisory management and other aspects. Excellent management team is the key of success in enterprises development.

\section{Introduction}

After China joined the WTO, the whole society participated in the division of labour system of the world economy, manufacturing industry developed rapidly, many labours began to flow into cities, the process of population urbanization made housing demand centralized and released in a short period of time, and then China's real estate industry ushered in a golden period of development, born. Many large enterprise groups such as Vanke, Heng da, poly and so on. But with the initial realization of China's industrialization, economic development has entered a "new normal" and the urbanization process is bound to bid farewell to the original period of high-speed growth. The reduction of demand side volume is bound to impact the original ecological system of the real estate industry through the supply and demand relationship. The environment faced by enterprises is no longer as loose as before, and the market is entering a more intense stage of survival of the fittest.

\section{Method introduction, data description and variable selection}

\subsection{Data description}

The data in this paper is from the financial report of Cathay Taiwan listed companies in 2015. 148 listed real estate companies are listed. Restricted by the measurement method, the author chooses the top 40 enterprises whose profits rank in the top 40. As the real estate industry is no longer in the period of high-speed growth, simply relying on volume expansion is no longer the way out for the development of enterprises. Only more refined operation and management, while increasing sales, 
can enterprises effectively reduce operating costs to ensure in the long run, the profit margin is used as a screening criterion. Some companies listed in the mainland of China and Hong Kong at the same time, this paper deletes the stock data of Hong Kong in the selection of enterprises, and only retains the A-share data as the research object.

\subsection{Variable selection}

\subsubsection{Total assets}

Total assets refer to all assets that can be occupied or used by a certain business entity and bring benefits to the main body. The method used in this paper is data envelopment analysis (DEA), in which multiple enterprises are used as decision-making units. In this case, the input factors are mainly the resources and costs in the process of enterprise operation. Total assets include current assets and non-current assets and other sub-items, which makes the concept of a certain degree of ambiguity and complexity, but it can reflect the total amount of resources invested in the business process from a relatively macro perspective. Total assets are a relatively effective index when limited variables can be selected.

\subsubsection{Operating costs}

Operating cost refers to the cost of goods sold, and the cost of services provided by the business entities within a single operating period. It can reflect the input of the business process. The rationality of the input variables included in the model is not discussed here. What needs to be explained is the choice between business cost and main business cost. Many scholars use data envelopment analysis (DEA) to study enterprises, using the main business cost, to better reflect the investment in the main development direction of enterprises. However, the real estate industry studied in this paper is in the transition period from rapid expansion to steady development. Many enterprises begin to implement diversified management strategies, such as Evergrande Finance, Evergrande Bingtuan, Evergrande Grain and Oil, etc. In this case, the use of operating costs reflects the problem more comprehensively than the main operating costs.

\subsubsection{Manpower cost}

The operation of real estate enterprises is different from that of manufacturing enterprises. Although there are a lot of fixed assets such as construction projects under construction, they mainly rely on human capital in operation, not factory machinery. In this case, the efficient use of human capital has become the key to the development of industry enterprises. Therefore, the author introduces the cost of human capital into the econometric model. Professional manager system is gradually taking shape in China. The proportion of senior managers in the company's human cost is gradually increasing, and their performance has a very significant impact on the development of enterprises. In view of this, two indicators are used here, one is the average employee's salary, the other is the executive salary of two.

\subsubsection{Operating income}

Business income refers to the total inflow of economic benefits formed in the daily business process of selling goods and providing services, which is divided into main business income and other business income. This paper mainly studies real estate enterprises, whose main business income refers to the income obtained from the management of real estate and related industries, is an important indicator to measure the competitiveness of real estate companies. But like the operating costs, the 
diversification of real estate management will inevitably bring a lot of non-main business income, in this context, this paper selects business income as an output variable.

\subsubsection{Corporate profits}

Enterprise profit is the result of enterprise's business activities, which plays a very important role in enterprise's management and sustainable development. It is directly related to the quality and efficiency of enterprise's development, and it is also an important measure of enterprise's performance in a certain period. Starting from the actual situation, in the real estate industry into a low-speed development period, compared with operating income, corporate profits can better reflect the overall operating capacity of enterprises, so as an output variable into the econometric model.

\subsection{Empirical results analysis}

Table 1: Results of efficiency analysis of 10 enterprises

\begin{tabular}{|c|c|c|c|c|}
\hline Name & Comprehensive & Technology & Scale & Limit \\
\hline Vanke A & 1 & 1 & 1 & \\
\hline Taiho Group & 0.913 & 0.945 & 0.967 & irs \\
\hline Poly Real Estate & 1 & 1 & 1 & \\
\hline $\begin{array}{c}\text { New lake middle } \\
\text { treasure }\end{array}$ & 0.936 & 1 & 0.936 & irs \\
\hline $\begin{array}{c}\text { Green land } \\
\text { holding }\end{array}$ & 1 & 1 & 1 & \\
\hline COFCO Property & 0.812 & 0.832 & 0.967 & drs \\
\hline $\begin{array}{l}\text { Merchant snake } \\
\text { mouth }\end{array}$ & 0.901 & 1 & 0.901 & drs \\
\hline Suning Universal & 1 & 1 & 1 & \\
\hline Chinese happiness & 0.906 & 0.977 & 0.928 & drs \\
\hline Chinese capital & 1 & 1 & 1 & \\
\hline
\end{tabular}

From Table 1, we can see that 13 of the 40 real estate enterprises have achieved comprehensive efficiency, accounting for $32.5 \%$ of the total, indicating that the real estate industry still has some room for improvement. However, the analysis of the real estate enterprises whose non-comprehensive efficiency has not reached 1 shows that although there is room for improvement, it is not very big. Among them, 12 enterprises 'comprehensive efficiency values are between 0.9 and $0.1,11$ enterprises are between 0.8 and 0.9 , and only 4 enterprises are below 0.8 , which are higher than 0 except the financial street. 7 , we can see that the listed real estate business is relatively mature. The profit margin can reflect the information of enterprise scale and income. Among the measurement results, the average factor comprehensive efficiency of the top 20 enterprises is $0.9489,7$ enterprises realize the comprehensive efficiency of 1 , the average factor comprehensive efficiency of the last 20 enterprises is $0.9032,6$ enterprises realize the comprehensive efficiency of 1 , and the industry exists. A certain degree of Matthew effect, at the same time, a larger profit margin really helps real estate enterprises to improve the efficiency of the use of factors, increase enterprise performance. However, only four enterprises realize the marginal increase in returns to scale. The real estate industry is no longer a good way to achieve growth by increasing investment alone. As can be seen from table 2, all enterprises have achieved no slack in output in terms of revenue. It shows that after years of operation and development, the major real estate companies have strong operational capacity in sales and can basically achieve the optimal allocation of resources in sales. This also shows that expanding sales is no longer the key path to promote enterprise development. In terms of profit slack, 22 of the 40 enterprises have profit slack, which shows that there is still a very big room for industry enterprises 
to improve in this respect. Among the top 20 enterprises, 11 Profit slack exists in one company, and 11 of the last 20 enterprises have profit slack, which shows that this problem is widespread in the industry.

\section{Concluding}

Based on the financial data of Listed Companies in 2015, this paper selects 40 real estate enterprises as the research object, using data analysis method to analyze the factors affecting enterprise performance and then draws the following two conclusions.

First, scale is still one of the development directions of real estate enterprises. Large-scale real estate enterprises have higher comprehensive efficiency and have certain advantages in realizing efficient allocation of resources. However, this advantage is no longer very significant. The gap is not large now, which once again proves that only by expanding investment can no longer support the healthy development of the real estate industry, enterprises need to invest more energy in improving the management level.

Secondly, the real estate industry has a certain degree of slack in profits, and there is a more significant Matthew effect, which shows that the industry (especially small and medium-sized real estate enterprises) need to adjust and improve the cost segmentation management. Human resource management is an important optimization direction. Many real estate enterprises can not provide good conditions for grass-roots employees to play their talents, resulting in a great waste of human capital, the industry urgently needs good management team. However, the redundancy of manpower cost in senior managers indicates that the industry needs to improve the corporate governance system, strengthen the supervision of professional managers, and reduce the principal-agent costs.

\section{References}

[1] Wang Meng Fei. Research on the market performance of highway industry based on SCP paradigm [D]. Chinana University, 2016.

[2] Liu Wei. Real estate trust investment fund performance evaluation and risk prevention and control research [D]. Beijing Institute of Technology, 2016.

[3] Gan Yenning. Research on the performance of reverse takeover in Chinese enterprises [D]. Beijing Institute of Technology, 2015.

[4] Byrunning. Research on Performance Evaluation of Listed Real Estate Enterprises Based on DEA Method [D]. Harbin Commercial University, 2015.

[5] Su Shu. Research on the performance of listed real estate companies in China based on DEA [D]. Chongqing University, 2007. 